\title{
Occurrence of Loma cf. salmonae in brook, brown and rainbow trout from Buford Trout Hatchery, Georgia, USA
}

\author{
Joel A. Bader ${ }^{1}$, Emmett B. Shotts $\mathrm{Jr}^{2, *}$, Walton L. Steffens ${ }^{3}$, Jiri Lom ${ }^{4}$ \\ ${ }^{1}$ USDA, Agriculture Research Service, Fish Diseases and Parasites Research Laboratory, Auburn, Alabama 36830, USA \\ ${ }^{2}$ National Fish Health Research Laboratory, Kearneysville, West Virginia 25430, USA \\ ${ }^{3}$ Department of Pathology, College of Veterinary Medicine, University of Georgia, Athens, Georgia 30601, USA \\ ${ }^{4}$ Institute of Parasitology, Czech Academy of Sciences, Ćeské Budějovice, Czech Republic
}

\begin{abstract}
During a 6 mo study of moribund trout from Buford hatchery, Buford, Georgia, USA, a Loma cf. salmonae microsporidian parasite was studied in the gills of brook trout Salvelinus fontinalis, brown trout Salmo trutta, and rainbow trout Oncorhynchus mykiss. This parasite was morphologically similar to L. salmonae and L. fontinalis but differed in spore size. Scanning and transmission electron microscopy demonstrated that xenomas were embedded in gill filaments. Transmission electron micrographs prepared from fresh tissue showed mature spores with 12 to 15 turns of their polar tube. Spore diameters for the Georgia strain from formalin-fixed gill tissues measured $3.5(\mathrm{SD} \pm 0.1)$ by $1.8(\mathrm{SD} \pm 0.1)$ $\mu \mathrm{m}$. Electron micrographs of formalin-fixed, deparaffinized tissues of rainbow trout from Pennsylvania and West Virginia show spores with a diameter of $3.5( \pm 0.2)$ by $1.7( \pm 0.1) \mu \mathrm{m}$ and $3.4( \pm 0.2)$ by $1.8( \pm 0.1)$ $\mu \mathrm{m}$, respectively. Transmission electron micrographs of spores from Pennsylvania and West Virginia show that mature spores from both states had 13 to 15 turns of their polar tubes. Measurements from transmission electron micrographs prepared from alcohol-fixed tissues from Virginia fish contained spores with a diameter of $3.0( \pm 0.3)$ by $1.1( \pm 0.3) \mu \mathrm{m}$ and 12 to 15 turns of their polar tubes. These measurements are consistent with $L$. salmonae and therefore suggest that the parasite is present on the east coast of the United States. During the height of the Georgia epizootic, the percentage of fish with observed xenomas reached $62.2 \%(\mathrm{~N}=87)$, and the highest number of xenomas counted per 10 gill filaments was $133(\mathrm{~N}=87)$. The microsporidian epizootic occurred either during the autumn months or when intake river water quality reached combined iron-manganese concentrations as high as 1.01 (mean 0.44, $\mathrm{SD} \pm 0.42$ ) $\mathrm{mg}^{-1}$
\end{abstract}

KEY WORDS: Brook trout - Brown trout Rainbow trout - Microsporidia - Loma salmonae - Loma cf. salmonae

\section{INTRODUCTION}

Loma is a relatively newly described genus (Putz et al. 1965, Morrison \& Sprague 1981) within the phylum Microspora (Sprague 1977. Canning \& Lom 1986). Loma contains 6 species, 2 of which infect primarily salmonid fishes, causing mortalities. L. salmonae has been noted in rainbow trout and steelhead Oncorhynchus mykiss, coho $O$. kisutch, kokanee O. nerka

- Addressee for correspondence.

E-mail: emmett_shotts@usgs.gov and chinook salmon O. tshawytscha in California, Alaska, and British Columbia (Wales \& Wolf 1955, Morrison \& Sprague 1981, Hauck 1984, Bekhti \& Bouix 1985, Magor 1987, Kent et al. 1989). This species was originally named Plistophora salmonae (Putz et al. 1965). It has spores that average 4.5 by $2.2 \mu \mathrm{m}$ in size in fixed state and have 14 to 17 turns of the polar tube. A second Loma species called $L$. fontinalis was first described in brook trout Salvelinus fontinalis from Nova Scotia. This species has highly vacuolated sporoblasts, an average size of resin-embedded spores of 3.7 by $2.2 \mu \mathrm{m}$, and either 12 to 14 turns of the polar 
tube (Morrison \& Sprague 1981) or 14 to 15 turns (Morrison \& Sprague 1983). Historically, these 2 species were thought to represent a single species (Morrison \& Sprague 1981). However, electron microscopic studies divided them into the 2 species (Morrison \& Sprague 1983). Separation into species was based primarily on size of fixed spores, number of turns in the polar tube, and alleged vacuolization of the sporoblast in $L$. fontinalis (Morrison \& Sprague 1983). However, as stated by Canning \& Lom (1986), characteristics of fresh spores need to be defined to determine whether the 2 species are really different.

Lesions associated with each of these parasites are similar and are most pronounced in gill tissue where cyst-like structures are primarily observed (Morrison \& Sprague 1981, Magor 1987). These structures represent host cells enlarged by the action of the parasite developing inside them. Weissenberg (1968) introduced the term 'xenoma' for these structures in which the parasite and host cell form an integrated entity. Xenomas are characteristic of microsporidian infections in fish (Weissenberg 1968, Roberts 1978). Lomainduced xenomas may cause hypertrophy of infected endothelial cells and occlusion of the gill lamellae (Magor 1987).

Georgia State trout hatcheries raise more than one million salmonids each year for stocking in State maintained trout waters (P. Markey, Georgia Department of Natural Resources, Buford Hatchery, pers. comm.). Forty percent of all fish raised by the State are produced at the Buford Trout Hatchery in Buford, Georgia, the largest of the State's 3 trout hatcheries. Since its inception in 1976, the Buford Trout Hatchery has experienced periodic outbreaks of disease, particularly in the fall (B. Couch, Georgia Department of Natural Resources, Buford Hatchery, pers, comm.). Grizzle (1981) studied fish health in 2 locations near the Buford Hatchery, one below the dam and one $19 \mathrm{~km}$ below the hatchery. Fish were sampled by electrofishing, examined for protozoan infections and cultured for bacterial and viral pathogens. Liver, kidney. and gill tissue were examined histologically for signs of disease. Water quality samples were collected in this study at high and low water time periods and examined for dissolved oxygen, ionized iron, and total iron and manganese. The concentration of manganese was found to be above safe levels for rainbow trout. Both Grizzle (1978) and Oglesby et al. (1978) attributed seasonal variations on manganese in the hatchery and river water as the cause of the fish kills. Jones Edmunds, and Associates, Inc. (1982) suspected that high levels of iron ( $\mathrm{Fe}$ ) and manganese ( $\mathrm{Mn}$ ) in the Chattahoochee River, which feeds the hatchery, contributed to the hatchery mortality and suggested that increasing water hardness would mitigate their toxic effects. Attempts to mitigate the effects of combined iron ( $\mathrm{Fe}$ ) and manganese ( $\mathrm{Mn}$ ) by increasing intake water hardness were unsuccessful in preventing annual autumn mortality (Couch 1990). Prior to 1991 . no comprehensive evaluation for infectious diseases had been conducted within the Buford facility. Recently, Markey et al. (1994) conducted a study of fish health in the Buford Hatchery and described lesions associated with a Loma infection.

This study further defines the description of the Loma microsporidian parasite previously found in the gills of trout in the southeastern United States (Markey et al. 1994). The intent of our study was to monitor the Buford Hatchery microsporidian epizootic beyond 1992, evaluate water quality factors which may contribute to the predisposition of trout to the parasite, examine the ultrastructure of the microsporidian parasite using electron microscopy and compare this parasite to other microsporidians found in diseased trout from other Eastern U.S. states.

\section{METHODS AND MATERIALS}

Study site. The Buford Trout Hatchery was chosen for this study because of its history of unexplained seasonal fish mortalities (Markey et al. 1994). The hatchery is located $2.5 \mathrm{~km}$ below Buford Dam and is supplied with Chattahoochee River water from the tailrace of Lake Lanier. Water level in the river is controlled by discharge from the dam and water quality varies widely during high-and low-water levels during the year. Salmonid fish grown at the hatchery include rainbow trout, brook trout and brown trout Salmo trutta. Each year a portion of the salmonids are hatched from eggs obtained from hatchery maintained brood fish and reared to a total length of 33 to $40 \mathrm{~cm}$, and released throughout northeastern Georgia. The hatchery maintains a well that provides water for a control site.

Fish. During a 6 mo sampling period (September 1992 through February 1993) a random sample of 8 to 10 brown trout, rainbow trout and brook trout was obtained every 2 wk from 4 river water fed raceways at the Buford Trout Hatchery. These fish were collected at the tail of the raceways near the screen. This location was chosen because most moribund fish tend to be found there. The sample often included moribund fish and fish without any obvious clinical signs of disease.

Throughout the sampling period, control fish were available. These fish were hatched from eggs obtained from the federal trout hatchery at Wahala, North Carolina, USA, and reared in plastic raceways in a hatchery facility supplied with well water. Early in the sample period a subset of these fish was trans- 
ferred into Buford Trout Hatchery raceways supplied with river water. Each month 2 to 4 control fish were examined for presence of xenomas and for morbidity. A comparison was made between these 2 groups of fish to determine when microsporidian infection occurred and how much mortality occurred in each group.

Water quality. Throughout the sampling period, monthly (except during December) water samples were collected from a raceway and from intake water. Intake water was collected at the same time as the raceway water and therefore was collected during various water flows, both high and low. However, no consideration was given to the actual water heights. These samples were collected and brought immediately for analysis to the United States Environmental Protection Agency Laboratory, Athens, GA, according to standard titrimetric methods for the examination of water and wastewater (APHA 1985). The water quality factors evaluated were: aluminum, cadmium, calcium, chloride, chromium, copper, fluorine, total iron, magnesium, total manganese, molybdenum, nickel, nitratenitrogen, phosphate, phosphorous, potassium, sodium, sulfate, and zinc. Temperature and dissolved oxygen (DO) data were obtained from the Markey et al. (1994) study that preceded the sampling period. Markey et al. (1994) obtained their water quality data from these sources.

Scanning and transmission electron microscopy. After euthanization with $>100 \mathrm{mg}$ of tricaine (MS-222) (Argent Chemical Laboratories, Redmond, WA, USA) gills, spleen, and kidney tissue were removed from each fish. For scanning electron microscopy (SEM), the gills from these fish were cut to size $(<20 \mathrm{~mm})$ and fixed for $24 \mathrm{~h}$ in either $2 \%$ glutaraldehyde in $0.1 \mathrm{M}$ phosphate buffer or $1 \%$ Acrolein in $0.1 \mathrm{M}$ cacodylate buffer. The tissues were washed twice in distilled water, dehydrated in a graded ethanol series, and critical point-dried (Tousimis Autosamdri 814, Tousimis Research Corporation, Rockville, MD, USA). Two gill filaments (or $1 \times 1 \mathrm{~mm}$ sections of tissue) from each fish were attached to aluminum stubs via Spot-O-Glue Labels (Avery Commercial Products Division, Azusa CA, USA). These stubs were then sputter-coated with approximately $20 \mathrm{~nm}$ of gold (Module sputter-coater, SPI Supplies Division of Structure Probe, Inc., West Chester, PA, USA). Finally, the gill filaments and tissues were imaged and photographed on a scanning electron microscope (JSM-35, JEOL, Tokyo, Japan) with an accelerating voltage of $15 \mathrm{keV}$.

Tissues used for transmission electron microscopy (TEM), were fixed in $2 \%$ glutaraldehyde in $0.1 \mathrm{M}$ cacodylate buffer, $2 \%$ formaldehyde, and $0.2 \%$ picric acid for $24 \mathrm{~h}$, rinsed in buffer, postfixed in $1 \%$ osmium tetroxide for $1 \mathrm{~h}$, dehydrated in an ethanol series and embedded in Spurr resin. Ultrathin sections were viewed and photographed in a JEM $100 \mathrm{~S}$ (JEOL) operating at $80 \mathrm{keV}$ or a JEM 1210 operating at $120 \mathrm{keV}$.

Additional gill samples embedded in paraffin blocks were obtained from West Virginia and Pennsylvania rainbow trout samples sent to Dr Blazer at the U.S. Fish and Wildlife National Fish Disease Diagnostic Laboratory in Leetown, West Virginia (Dr V. Blazer pers. comm.). These tissues were excised from the blocks, deparaffinized by soaking $24 \mathrm{~h}$ in xylene, and prepared for TEM. Rainbow trout gill samples from Virginia were also obtained from Dr Blazer and sent to us in $65 \%$ ethyl alcohol. These tissues were processed, and prepared for TEM.

Prevalence of diseases. During the sample period, infectious disease outbreaks were monitored. Fish without obvious clinical signs of disease were examined in the same manner as were the moribund fish, but if no etiology was found, these fish were considered normal and were used as a baseline health reference. Each of the fish sampled was examined for bacterial and parasitic diseases, as well as for water quality or nutritional diseases. Necropsies were performed on each fish as described by Stoskopf (1993). Protozoans observed in wet mounts of gill and skin were counted (Hoffman 1967), and any bacteria present were isolated (Amos 1985). Throughout the sample period, the frequency of microsporidian infection in each wet count was determined by light microscopy. The presence of 1 or more xenomas within 10 gill filaments of a fish was designated positive for microsporidian infection. Throughout the sample period, the number of xenomas in $10 \mathrm{gill}$ filaments was counted by light microscopy.

Mature spore morphologic characteristics. The size of mature spores for the Georgia strains was determined by measurement of the spores from fresh tissue by light microscopy (Georgia $N=100$ ). Spore sizes for West Virginia $(N=20)$ and Pennsylvania $(N=20)$ strains were determined from transmission electron micrographs of formalin-fixed tissue because fresh tissue was unavailable. Virginia $(\mathrm{N}=10)$ spore size was determined from alcohol-fixed gill material via TEM. Other morphologic characteristics were determined via TEM. Internal morphologic characteristics other than polar tube turns could not be determined in the Virginia samples, due to the alcohol fixation.

Statistical analysis. Standard statistical analysis was used to determine means and standard deviations of spore measurements. One-way ANOVA at $p=0.5$ was used to compare sample means. All calculations were performed using a Macintosh computer with StatView $512+$ software (BrainPower, Inc, Calabases, CA) 


\section{RESULTS}

Fish

The microsporidian-infected fish examined in this study exhibited the following clinical signs: flared operculum with pale to lightly hemorrhagic gills, lethargic swimming and feeding, and pale white ovoid macroscopic gill lesions (xenomas). Xenomas were often covered by respiratory epithelial cells. The microsporidian infections were seen in all 3 species examined. However, the parasite was absent from the fish held in well water. The control developed xenomas later, 4 mo after they were introduced into raceways receiving river water.

\section{Water quality}

Mean water quality data from each month throughout the sampling period (except December) are presented in Table 1. Markey et al. (1994) presented data for $90 \mathrm{l}$ troughs during August 1991 through January 1992; temperatures ranged from 10.6 to $15.5^{\circ} \mathrm{C}$ and DO from 4.8 to $7.0 \mathrm{mg} \mathrm{l}^{-1}$. The control $90 \mathrm{l}$ troughs supplied with well water remained fairly constant for temperature, $\mathrm{pH}$ and $\mathrm{DO}\left(15 \pm 0.5^{\circ} \mathrm{C}\right.$ and DO 7.9 to 6.4$)$ (Markey et al. 1994). Combined total ion concentra-

Table 1 . Means $\pm \mathrm{SD}$ of water quality characteristics in $\mathrm{mg} \mathrm{l}^{-1}$ measured monthly from September 1992 through February 1993 at the Buford Hatchery, Buford, Georgia, USA. N = 5 (no December water data)

\begin{tabular}{lcc}
$\begin{array}{l}\text { Water } \\
\text { characteristic }\end{array}$ & \multicolumn{2}{c}{ Water source } \\
\hline $\mathrm{P}$ & $0.270 \pm 0.408$ & $0.180 \pm 0.178$ \\
$\mathrm{~K}$ & $1.622 \pm 0.878$ & $1.664 \pm 0.332$ \\
$\mathrm{Ca}$ & $2.308 \pm 0.407$ & $2.216 \pm 0.312$ \\
$\mathrm{Mg}$ & $1.020 \pm 0.051$ & $0.984 \pm 0.056$ \\
$\mathrm{Mo}$ & $0.010 \pm 0.000$ & $0.016 \pm 0.013$ \\
$\mathrm{Fe}$ & $0.224 \pm 0.245$ & $0.326 \pm 0.304$ \\
$\mathrm{Al}$ & $0.031 \pm 0.031$ & $0.064 \pm 0.055$ \\
$\mathrm{Cu}$ & $0.009 \pm 0.002$ & $0.009 \pm 0.002$ \\
$\mathrm{Na}$ & $2.160 \pm 0.376$ & $2.072 \pm 0.557$ \\
$\mathrm{~Pb}$ & $0.025 \pm 0.005$ & $0.025 \pm 0.005$ \\
$\mathrm{Cd}$ & $0.027 \pm 0.040$ & $0.009 \pm 0.002$ \\
$\mathrm{Ni}$ & $0.027 \pm 0.040$ & $0.009 \pm 0.002$ \\
$\mathrm{~F}$ & $0.500 \pm 0.000$ & $0.500 \pm 0.000$ \\
$\mathrm{Cl}$ & $2.097 \pm 1.653$ & $2.192 \pm 0.931$ \\
$\mathrm{Mn}$ & $0.075 \pm 0.127$ & $0.118 \pm 0.147$ \\
$\mathrm{Cr}$ & $0.045 \pm 0.050$ & $0.010 \pm 0.000$ \\
$\mathrm{Zn}$ & $0.060 \pm 0.111$ & $0.144 \pm 0.299$ \\
$\mathrm{NO}_{3}$-N & $0.358 \pm 0.218$ & $0.288 \pm 0.088$ \\
$\mathrm{SO}_{4}$ & $1.980 \pm 0.302$ & $1.978 \pm 0.528$ \\
$\mathrm{PO}_{4}$ & $0.500 \pm 0.000$ & $0.795 \pm 0.914$ \\
$\mathrm{Combined} \mathrm{Fe} \mathrm{and} \mathrm{Mn}$ & $0.299 \pm 0.360$ & $0.440 \pm 0.440$ \\
& &
\end{tabular}

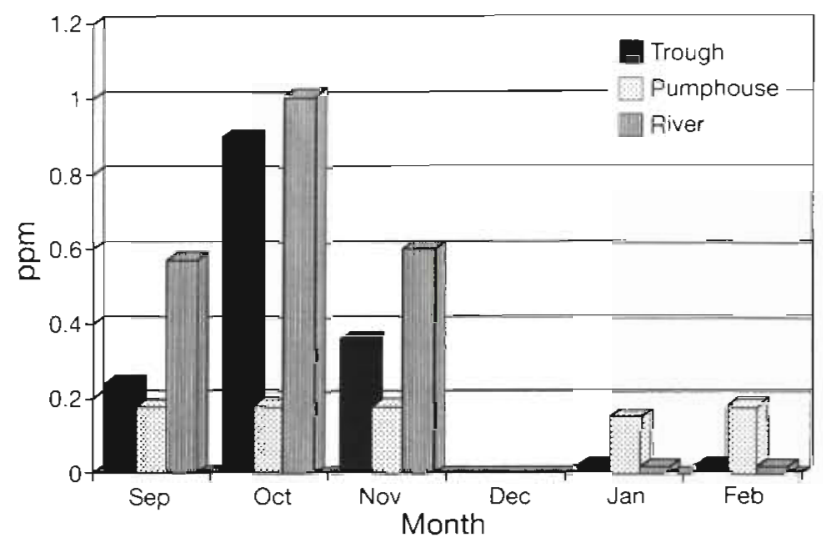

Fig. 1. Combined iron and manganese concentrations from September 1992 through February 1993 for intake and river waters at the Buford Hatchery, Buford, Georgia, USA. N = 5 (no December water data)

tions of iron and manganese fluctuated throughout the sampling period in river and hatchery water (trough and pumphouse) (Fig. 1). The months of September through November had total iron and manganese above $0.2 \mathrm{ppm}$. During the same period, the total iron and manganese in the well water was almost constant (Fig. 1).

\section{Prevalence of diseases}

Pathogens identified from moribund fish included protozoa (other than microsporidia), bacteria, microsporidia, monogeneans, undetermined pathogens, and fungi (Fig. 2). Protozoa (other than microsporidia), observed were predominately Ichthyophthirus multifilis and Trichodinella spp. Bacterial organisms included Yersinia ruckerii, Flavobacterium columnare, F. psychrophilum, Aeromonas hydrophila, and $A$. salmonicida. Microsporidian pathogens were exclusively the Loma-like spp. Monogeneans included dactylogyrids and Gyrodactylus spp. Undeter-

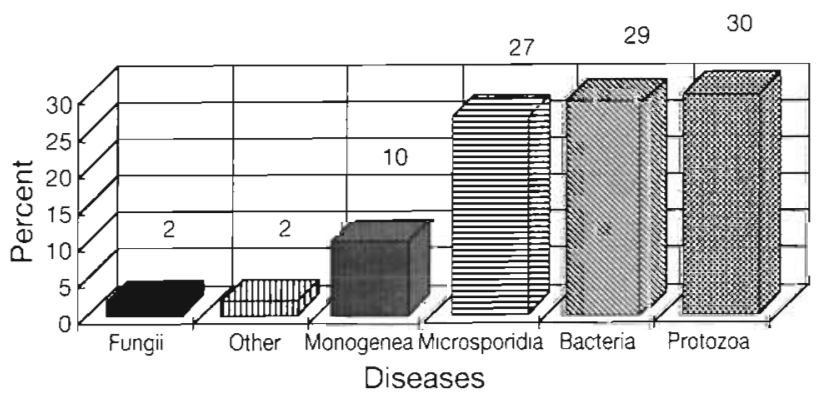

Fig. 2. Prevalence of diseases in sampled brook, brown, and rainbow trout from Buford Hatchery during September 1992 through February 1993. $N=87$ 


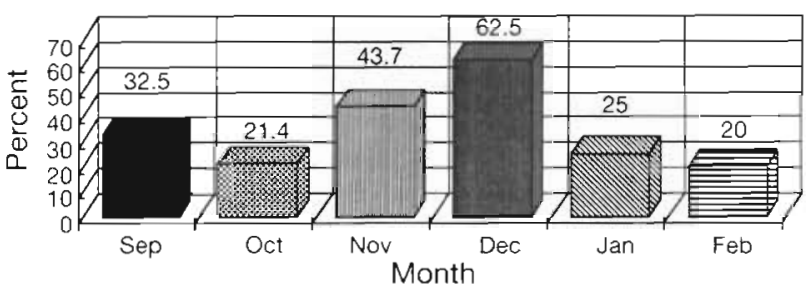

Fig. 3. Prevalance of Loma spp. in sampled brook, brown, and rainbow trout from Buford Hatchery during September 1992 through February 1993. $\mathrm{N}=87$

mined pathogens included morbidity without an etiology including water quality and nutritional diseases. Fungi included unclassified Oomycetes. Fish with no clinical signs of disease when examined revealed numbers of monogeneans and protozoa $<2$ per 10 gill filaments, and had no culturable bacteria

The prevalence of microsporidian infections among the fish sampled peaked in December at $62.5 \%(\mathrm{~N}=$ 87 ), but was above $21 \%$ throughout the autumn and up to December (Fig. 3). The number of xenomas per 10 gill filaments averaged $90(\mathrm{SD} \pm 43)$ and was highest from October through November, peaking at 133 in November (Fig. 4). After the number of xenomas peaked, they rapidly disappeared.

\section{Morphologic characteristics of mature spores}

Light and electron microscopy indicated a similar Loma cf. microsporidian parasite from xenomas found in gill tissue from all states sampled (Table 2). Xenomas were evident by SEM (micrograph not shown). Cross-sections of xenomas showed large numbers of spores at varying stages of maturity (micrograph not shown). The mean dimensions and number of turns of the polar tube observed in mature spores from Georgia, Pennsylvania, West Virginia, and Virginia were not significantly different at $\mathrm{p}=$ 0.5 (Table 2).

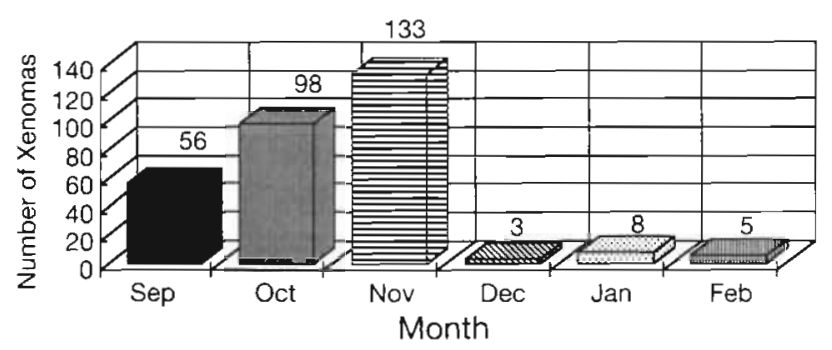

Fig. 4. Average number of xenomas per 10 gill filaments in sampled brook, brown, and rainbow trout from Buford Hatchery during September 1992 through February 1993. $N=87$

\section{DISCUSSION}

The findings of this study suggest that all 3 species of cultured trout were susceptible to the Loma-like microsporidian. To our knowledge, this is the first description of a Loma-like microsporidian being reported from either brown or brook trout in the USA

The microsporidian parasite described is consistent with the published morphologic and TEM description of a parasite in various tissues of rainbow trout with mature spore size of $3.6( \pm 0.1)$ by $1.7( \pm 0.1) \mu \mathrm{m}$ in fixed tissues and of $4.2(\mathrm{SD} \pm 0.1) \times 2.6 \mu \mathrm{m}$ in fresh spores (Markey et al. 1994). Their measurements from fixed tissue are 20 to $40 \%$ greater than the $3.5( \pm 0.1)$ by 1.8 $( \pm 0.1) \mu \mathrm{m}$ measurements noted in this study. Spore measurements from Pennsylvania and West Virginia fish are not significantly different to spores obtained from Georgia fish tissue and are consistent with the Markey et al. (1994) measurements of formalin-fixed tissue. The Virginia strain was 15 to $20 \%$ smaller than the other strains, which may reflect its true size or be a result of shrinkage due to its alcohol preservation prior to preparation for TEM. The mature spore measurements from all states were smaller than for Loma species previously described in salmonid fishes in all but the Markey et al. (1994) study. L. salmonae spores measure 4.5-4.0 × 2.3-2.1 $\mu \mathrm{m}$ (Putz et al. 1965, Magor 1987, Kent et al. 1989) and L. fontinalis spores measure $3.7 \times 2.2 \mu \mathrm{m}$ (Morrison \& Sprague 1983). While spore measurements are closer to those reported for $L$. fontinalis, the ultrastructure and morphology of the parasite appears closer to $L$. salmonae. Like L. salmonae spores previously described in salmonids, the mature spore has 14 to 15 turns of the polar tube and an anteriorly coiled polar tube which is attached to a distinctive polar cap (Putz et al. 1965, Magor 1987, Kent et al. 1989). Based upon current observations, we prefer to call this organism Loma cf. salmonae and defer definitive speciation to other researchers.

Infections caused by the Loma cf. salmonae microsporidian parasite at the Buford Trout Hatchery may have impacted the potential trout production at the hatchery. As many as $27 \%$ of the moribund fish at the hatchery during the autumn and early winter were diagnosed as being infected with this parasite. This number was third in prevalence only to bacterial and protozoan infections, which historically have been problems in this hatchery. This may explain why the microsporidian was not observed earlier. Yersinia ruckeri infections and protozoan species such as Ichthyophthirius multifiliis along with poor water quality have long been the suspected etiologies of the hatchery's unexplained mortalities. Microsporidia have not been previously evaluated as to the role they play in hatchery mortality. 
Histologic examinations of monitored fish revealed hypertrophied cyst-like structures in the gills of some

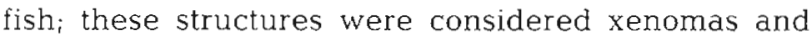
were subsequently described as having the microsporidian parasite within them. Similar structures were observed within various fish tissues, including the spleen, heart and gills. These parasites were viewed by TEM and the mature spores were measured by light microscopy examination of 20 spores in thick section. These mature spores had the following characteristics: spore dimensions $3.6( \pm 0.1) \times 1.7( \pm 0.1) \mu \mathrm{m}$, a polar tube diagonally located in the anterior third of the spore and 14 to 17 turns of the polar tube

This study explored the possible relationship of combined iron and manganese concentration to prevalence (percent fish infected) and intensity (xenoma number per 10 gill filaments) of microsporidian infection at the Buford Hatchery. This data suggest that a relationship may exist between microsporidian disease and total iron and manganese concentration. Concentrations of these ions were highest in the months preceding the highest incidence of the microsporidian infection. There appears to be a time lag between peak number of noted xenomas and highest incidence of microsporidian infection. This may be explained by the fact that xenoma numbers peak prior to their rupture and subsequent release of spores. These spores then infect other fish in the population, thereby ensuring the continuation of the epizootic and increasing the severity of the infection, which is greatest in December (Markey et al. 1994). Further research will be necessary to determine the exact relationship between total iron and manganese, microsporidian infectivity, and disease severity.

Acknowledgements. This study was supported in part by funds from the Georgia Department of Natural Resources. We also thank the following individuals: Bill Couch and the staff of the Buford Trout Hatchery, Pat Markey, Dr Blazer of the National Fish Disease Laboratory in Leetown, WV, for supplying paraffin sections of infected fish tissue from West Virginia and Pennsylvania and alcohol-preserved gill samples from Virginia, and Mary Ard and the staff of the University of Georgia Electron Microscopy Laboratory.

\section{LITERATURE CITED}

APHA (American Public Health Association), American Water Works Association, and Water Pollution Control Federation (1985) Standard methods for the examination of water and wastewater. APHA, Washington, DC

Amos KH (1985) Methods for the detection of certain bacterial diseases. In: Amos KH (ed) Procedures for the detection and identification of certain fish pathogens, 3rd edn. Fish Health Section, American Fisheries Society, Bethesda, MD, p $34-73$

Bekhti M, Bouix G (1985) Loma salmonae (Putz, Hoffman et Dunn, 1.965) et Loma diplodae n. sp. Microsporidia para- sites de branchies de poissons teleosteans implantation et données ultrastructurales. Protistologica 21:47-49

Canning EU, Lom J (1986) Introduction to the Microsporidia. In: Canning EU (ed) The microsporidia of vertebrates. Academic Press, London, p 1-134

Couch B (1990) Experimental addition of calcium chloride to increase water hardness and fish production at Buford Hatchery. Georgia Department of Natural Resources, Game and Fish Division, Project No. F-25, Atlanta

Grizzle JM (1978) Fish health in the tailwaters of Buford Dam, Georgia. Proc Annu Conf Southeast Assoc Fish Wildlife Agencies 33:535-548

Grizzle JM (1981) Effects of hypolimnetic discharge on fish heath below a reservoir. Trans Am Fish Soc 110:29-43

Hauck AK (1984) A mortality and associated tissue reactions of chinook salmon, Oncorhynchus tshawytscha (Walbaum), caused by the microsporidan Loma sp. J Fish Dis $7: 217-229$

Hoffman GL (1967) Methods. In: Hoffman GL (ed) Parasites of North American freshwater fishes. University of California Press, Berkeley, p 6-10

Jones, Edmunds, and Associates, Inc (1982) Final report for bioassay experiment lo determine water quality impacts related to trout mortality at a hatchery down stream of Lake Sidney Lanier, Georgia. Contract No. DACW01-80-C-0368. Jones, Edmunds, and Associates, Inc, Gainesville, FL

Kent ML, Elliott DG, Groff JM, Hedrick RP (1989) Loma salmonae (Protozoa: Microspora) infections in seawater reared coho salmon Oncorhynchus kisutch. Aquaculture 80:211-222

Magor BG (1987) First report of Loma sp. (Microsporida) in juvenile coho salmon (Oncorhynchus kisutch) from Vancouver Island, British Columbia. Can J Zool 65:751-752

Markey P, Blazer VS, Ewing MS, Kocan KM (1994) Loma sp. in salmonids from the eastern United States: associated lesions in rainbow trout. J Aquat Anim Health 6:318-328

Morrison CM, Sprague V (1981) Microsporidian parasites in the gills of salmonid fishes. J Fish Dis 4:371-386

Morrison CM, Sprague V (1983) Loma salmonae (Putz, Hoffman \& Dunbar, 1965) in the rainbow trout, Salmo gairdneri Richardson, and L. fontinalis sp. nov. (Microsporidia) in the brook trout, Salvelinus fontinalis (Mitchill). J Fish Dis 6:345-353

Oglesby GB, Noell, WC, Delo HO, Dyer WA, England RH, Fatora RR, Grizzle JM, Deutsch SF (1978) Toxic substances in discharges of hypolimnetic waters from a seasonally stratified impoundment. Environ Conserv 5:287-293

Putz RE, Hoffma GL, Dunbar CE (1965) Two new species of Plistophora (microsporidia) from north American fish with synopsis of microsporidea of fresh water and euryhaline fishes. J Protozool 12:228-236

Roberts RJ (1978) The parasitology of teleosts. In: Roberts RJ (ed) Fish pathology. MacMillan, New York, p 144-183

Sprague V (1977) Annotated list of species of Microsporidia. In: Bulla LA, Cheng TC (eds) Systematics of the microsporidia, Comparative pathology, Vol 2. Plenum Press, New York, p 31-334

Stoskopf MK (1993) Clinical examination and procedures In: Stoskopf MK (ed) Fish medicine. WB Saunders Co. Philadelphia, p 62-78

Wales $\mathrm{JH}$, Wolf $\mathrm{H}$ (1955) Three protozoan diseases of trout in California. Caljf Fish Game 41:183-187

Weissenberg R (1968) Intracellular development of the microsporidan Glugea anomala Moniez in hypertrophying migratory cells of the fish. Gasterosteus aculeatus L., an example of the formation of 'xenoma' tumours. J Protozool 15:44-57

Submitted: April 3, 1997; Accepted: June 23, 1998

Proofs received from author(s): November 3, 1998 